\title{
A Rare Complication of the Treatment of Simple Renal Cysts: Nephrostomy Catheter Breakage after Alcohol Treatment and Laparoscopic Management
}

\author{
Basit Böbrek Kistlerinin Tedavisinde Nadir Görülen Bir Komplikasyon: \\ Nefrostomi Kateterinin Alkol Tedavisi Sonrası Kopması ve Laparoskopik \\ Tedavisi
}

\author{
Barbaros Başeskioğlu, Ali Ülgen \\ Osmangazi University Faculty of Medicine, Department of Urology, Eskişehir, Turkey
}

\begin{abstract}
The prevalence of simple renal cysts increases with age. Simple renal cyst aspiration and sclerotherapy with percutaneous nephrostomy catheter is frequently used in urological practice. This method can be applied under local anesthesia and various complications of this method have been reported. In this paper, we report an unusual complication of this method; the distal part of the nephrostomy catheter had separated after renal cyst aspiration and laparoscopic procedure was used to remove the end part of the catheter which remained within the cyst wall in the pararenal area.
\end{abstract}

Keywords

Simple cyst, alcohol, laparoscopy

\section{ÖZ}

Basit böbrek kistleri görülme sıklığı yaş ile artar. Perkütan nefrostomi kateteri ile böbrek kist aspirasyonu ve kist duvarları içine sklerozan madde enjeksiyonu üroloji pratiğinde sık kullanılan bir yöntemdir. Lokal anestezi altında uygulanan bu yöntemin çeşitli komplikasyonları bildirilmiştir. Bu olgu sunumunda perkütan nefrostomi yöntemine ait beklenmedik bir komplikasyon olan kist aspirasyonu sonrası nefrostomi kateterinin distal uç kısmının kopması ve pararenal lojda kistik duvarın içinde kalan bu kateter ucunun laparoskopik yöntemle çıkarılması sunulmuştur.

Anahtar Kelimeler

Basit kist, alkol, laparoskopi

\section{Introduction}

Simple renal cysts are non-neoplastic disease of renal parenchyma. The prevalence of simple renal cysts among individuals aged 40 and 60 years and older is 20\% and 33\%, respectively. No treatment for simple renal cysts is required in asymptomatic patients. It is necessary to treat renal cysts causing flank pain, hypertension, hematuria, infection, and collecting system compression. In the literature, aspiration technique with percutaneous nephrostomy catheter with or without sclerosing agent, open cyst excision and recently reported laparoscopic cyst excision methods are used for the treatment of simple renal cysts.

One of these methods, percutaneous nephrostomy is easily applicable but major complications, such as bleeding that may require blood transfusion, septicemia, pleura, liver, spleen and colon injuries have been reported in the literature. In this report, removal of the distal part of the nephrostomy catheter that was separated in the retroperitoneal area was managed by laparoscopic technique.

\section{Case Presentation}

A 57-year-old female patient with a left renal cyst has been followed for 15 years. She had an increasing left flank pain for the past six months. Abdominal ultrasound demonstrated an anechoic cyst measuring $53 \times 51 \mathrm{~mm}$ in the lower pole of the left kidney. Using ultrasound guidance, percutaneous nephrostomy catheter was placed into the cyst under local anesthesia and clear cyst fluid was aspirated. Percent of ninety-six alcohol was used as sclerosing agent and the nephrostomy catheter was clamped for 20 minutes. The catheter was removed on the first day. When the catheter was removed, it was observed that the distal part remained in the patient. On plain radiography, radiopacity indicating the tip of catheter was observed. Computed tomography showed, catheter laying in posterolateral cortex in the left kidney (Figure 1a, b). Laparoscopic removal of the catheter was decided. At first, a $10 \mathrm{~mm}$ trocar was placed into the abdomen using the Hasson technique. Then, two $5 \mathrm{~mm}$ trocars were 


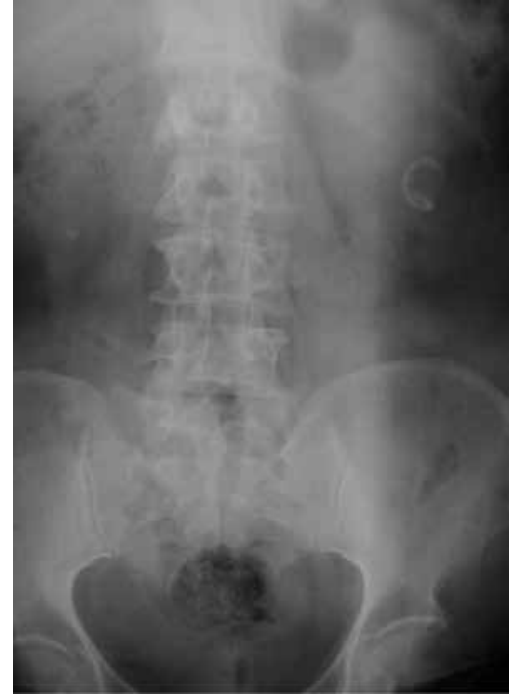

Figure 1a. Radiopacity of the separated part of the catheter in plain radiography

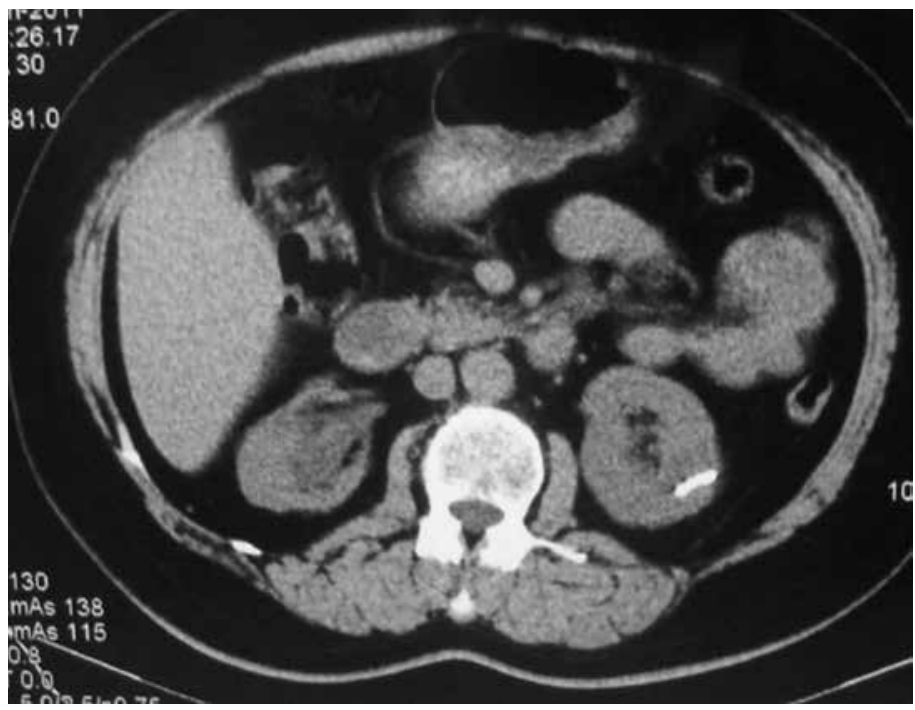

Figure $1 \mathrm{~b}$. Catheter in the cyst wall, posterior to the kidney in abdominal computed tomography

placed superior to the spina iliaca anterior superior and inferior to the $12^{\text {th }}$ costa in the anterior axillary line. After the colon was deviated, adhesions were seen in the retroperitoneal region. The tissue surrounding this region was very fibrotic due to the alcohol treatment. The wall of the cyst was opened and the catheter was observed. After sharp and blunt dissection, the catheter was removed via $5 \mathrm{~mm}$ port (Figure 2a, b). Drainage catheter was not placed.

\section{Discussion}

The kidneys are among organs that cysts are detected frequently (1). Renal cysts detected incidentally or after symptoms must classified according to the Bosniak classification because of malignancy potential or other incidents. Category 1 and 2 cysts according to the Bosniak classification are considered as simple renal cysts; type 3 and 4 are as complicated renal cysts. Simple renal cysts appear in $5 \%$ of all abdomen ultrasounds performed with any reason in all age groups. This kind of renal cysts are usually unilateral, originated

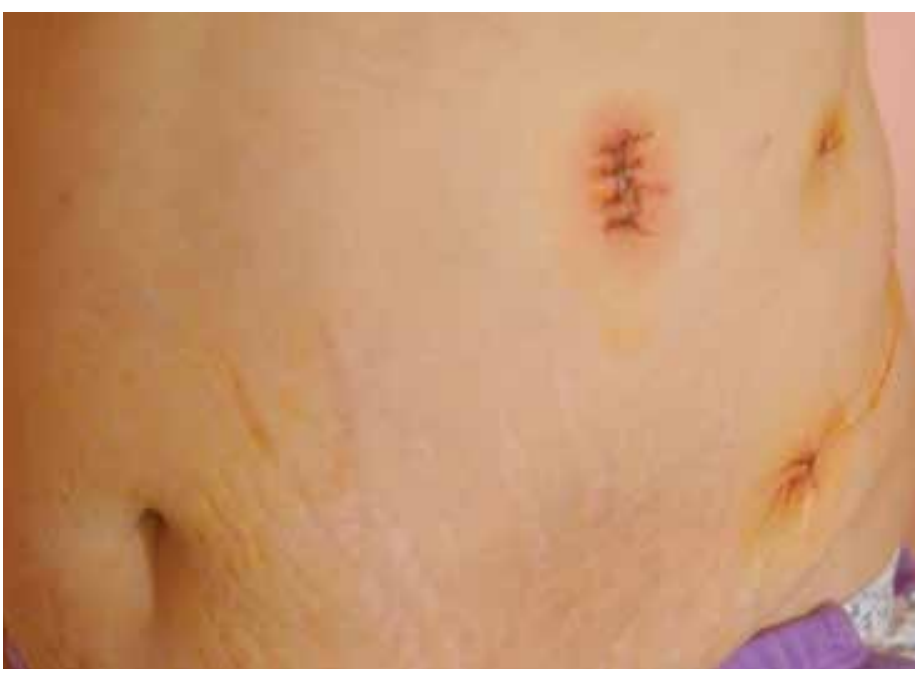

Figure 2a. Postoperative view of trocar localizations

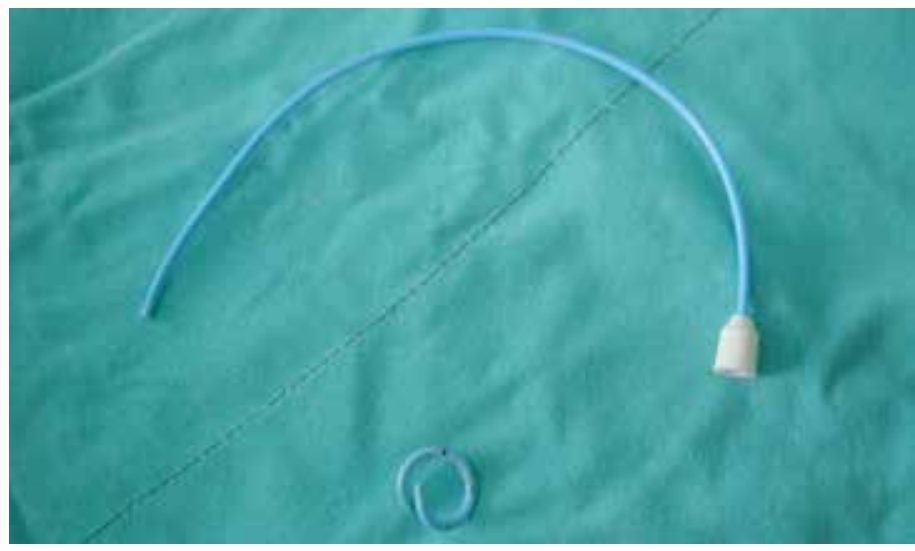

Figure 2 b. Postoperative view of nephrostomy catheter and separated distal part

from the collecting ducts and typically located in the cortex (2). The purpose of the treatment of simple cysts is to resolve the symptoms e.g. flank pain and/or complications, such as hemorrhages, infection, hydronephrosis and hypertension. Percutaneous cyst aspiration with or without sclerotherapy under ultrasound guidance and open or laparoscopic cyst excision are treatment of choices. The average rate of recurrence and residual cyst after percutaneous aspiration has been reported to be $30 \%$. Local and systemic complications following sclerotherapy due to alcohol injection and close monitoring have been reported (3). In the open renal cyst decortication method, morbidity and mortality rates arising from laparotomy are high. Disadvantages of laparoscopic procedure include risks of vascular and intraperitoneal organ injury, and difficulty in kidney mobilization. Lower renal cyst recurrence rates, shorter hospitalization time and lower mortality and morbidity rates featured laparoscopic approach (3).

Percutaneous nephrostomy under ultrasound guidance is described approximately 40 years ago (4) and performed in drainage of the upper urinary system in obstructive uropathy due to supra-or infra-vesical obstruction, drainage of pyonephrosis, and drainage of hemorrhages after percutaneous nephrolitotomy up to date. Besides, it is a minimally invasive procedure alternative to the open or laparoscopic cyst excision methods in simple renal cyst treatment. 
The rates of hemorrhage and septic shock after percutaneous nephrostomy are 1-4\% and 1-9\% (5), respectively. Other major complications include failure of procedure, and liver, spleen, colon, and pleura injuries. Urine extravasation and urination with clot are considered to be minor complications. In the literature, extreme complications, such as misplacement of nephrostomy catheter into the renal vein, inferior vena cava (6), and right atrium (7) have been reported. In our case report, unity/integrity of the catheter was destroyed and the distal end remained in the pararenal region. This kind of complication has not been previously reported and separated distal end was considered as a foreign body. Foreign bodies, such as intrauterine devices for contraception that displaced to another space, forgotten sponge and surgical instruments, and sharp foodstuff that may cause perforation of the gastrointestinal system cause more than 1500 operations annually (8). Intra-or extra-abdominal foreign bodies cause local irritation and local and systemic infection. Therefore, these foreign bodies must be treated properly as soon as identified. Features, location, symptoms of foreign body and general situation of the patient manipulate the treatment option, but the purpose has to be extraction of the foreign body in a single session. For this purpose, endoscopic, laparoscopic or open surgical techniques may be performed.

The abdominal cavity and retroperitoneal space are better evaluated in the laparoscopic method and reflection of the light provides metallic foreign body to be distinguished easily from other tissues. Laparoscopy, as a minimally invasive technique with small incisions, allows lower rates of postoperative infection, pain and postoperative morbidity. Therefore, we used laparoscopic method to remove the part of the nephrostomy catheter. In this case, transperitoneal approach was used considering the risk of complication due to possible adhesions.

\section{Ethics}

Informed Consent: Consent form was filled out by all participants. Peer-review: Internal peer-reviewed.

\section{Authorship Contributions}

Surgical and Medical Practices: Barbaros Başeskioğlu, Concept: Barbaros Başeskioğlu, Design: Barbaros Başeskioğlu, Data Collection or Processing: Ali Ülgen, Analysis or Interpretation: Barbaros Başeskioğlu, Ali Ülgen, Literature Search: Ali Ülgen, Writing: Barbaros Başeskioğlu.

Conflict of Interest: No conflict of interest was declared by the authors.

Financial Disclosure: The authors declared that this study has received no financial support.

\section{References}

1. Laucks SP Jr, McLachlan MSF. Aging and simple renal cysts of the kidney. Br J Radiol 1981;54:12-14.

2. Guazzoni G, Montorsi F, Bergamaschi F, Consonni $P$, Bellinzoni $P$, Centemero A, Rigatti P. Laparoscopic unroofing of simple renal cysts. Urology 1994;43:154-159.

3. Radecka $E_{1}$ Brehmer $M$, Holmgren $K$, Magnusson A. Complications associated with percutaneous nephrolithotripsy: supra-versus subcostal access. A retrospective study. Acta Radiol 2003;44:447-451.

4. Pedersen JF. Percutaneous nephrostomy guided by ultrasound. J Urol 1974;112:157-159.

5. Ramchandani P, Cardella JF, Grassi CJ, Roberts AC, Sacks D, Schwartzberg MS, Lewis CA; Society of Interventional Radiology Standards of Practice Committee. Quality improvement guidelines for percutaneous nephrostomy. J Vasc Interv Radiol 2003;14:277-281.

6. Mazzucchi E, Mitre A, Brito A, Arap M, Murta C, Srougi M. Intravenous misplacement of the nephrostomy catheter following percutaneous nephrostolithotomy: two case reports. Clinics (Sao Paulo) 2009;64:69-70.

7. Dias-Filho $A C$, Coaracy $G A$, Borges $W$. Right atrial migration of nephrostomy catheter. Int Braz J Urol 2005;31:470-471.

8. Gawande AA, Studdert DM, Orav EJ, Brennan TA, Zinner MJ. Risk factors for retained instruments and sponges after surgery. $N$ Engl J Med 2003;348:229-235. 